\title{
Effect of oestradiol on mRNA encoding GnRH receptor in pituitary tissue of orchidectomized sheep passively immunized against GnRH
}

\author{
B. M. Adams, H. Sakurai, and T. E. Adams* \\ Department of Animal Science, University of California, Davis, CA 95616, USA
}

\begin{abstract}
The effect of oestradiol on tissue concentrations of GnRH receptor and mRNA encoding $\mathrm{GnRH}$ receptor was assessed in orchidectomized sheep (wethers) made deficient in GnRH by passive immunization. Wethers were assigned to one of four groups ( $n=6$ animals per group). Animals in groups 2 and 4 received ovine anti-GnRH sera $(200 \mathrm{ml}$; i.v.) at passive immunization, while antisera against the carrier protein was administered to wethers in groups $\mathrm{I}$ and 3. Oestradiol was delivered as a continuous infusion $\left(2 \mu \mathrm{g} \mathrm{h}^{-1}\right)$ to wethers in groups 1 and 2. Animals in groups 3 and 4 were infused with vehicle alone. Anterior pituitary tissue was collected at the end of the $48 \mathrm{~h}$ infusion. Anti-GnRH sera induced a rapid reduction in the serum concentration of $\mathrm{LH}$. Continuous delivery of oestradiol resulted in a twofold increase $(P<0.05)$ in tissue concentration of $\mathrm{GnRH}$ receptor. This oestradiolinduced response was manifest even in wethers in which endogenous $\mathrm{GnRH}$ had been neutralized by passive immunization. Conversely, infusion of oestradiol increased $(P<0.05)$, and intravenous administration of anti-GnRH sera decreased $(P<0.05)$, concentrations of mRNA encoding $\mathrm{GnRH}$ receptor in pituitary tissue. When delivered in combination, anti-GnRH sera reduced $(P<0.05)$, but did not eliminate, the oestradiol-induced augmentation of steady-state concentrations of mRNA encoding $\mathrm{GnRH}$ receptor. These data demonstrate that the basal concentration of mRNA encoding GnRH receptor is dependent on continued GnRH stimulation. In contrast, the oestradiol-induced increase in steady-state concentration of mRNA encoding GnRH receptor is manifest even in the absence of GnRH.
\end{abstract}

\section{Introduction}

Steady-state concentrations of GnRH receptor and mRNA encoding GnRH receptor in pituitary tissue are increased during the preovulatory period in sheep (Padmanabhan et al., 1995) and rodents (Bauer-Dantoin et al., 1993). Oestrogenic input during the preovulatory period appears to be involved in this process (Brooks et al., 1993). Indeed, oestrogenic stimulation increases steady-state concentrations of $\mathrm{GnRH}$ receptor and mRNA encoding GnRH receptor in ovariectomized sheep (Turzillo et al., 1994; Hamernik et al., 1995) and rats (Kaiser et al., 1993). Similarly, tissue concentrations of GnRH receptor and mRNA encoding GnRH receptor rapidly decay after withdrawal of the oestrogenic stimulus (Adams et al., 1996).

Pituitary tissue concentrations of $\mathrm{GnRH}$ receptor and mRNA encoding GnRH receptor are also dependent on hypothalamic stimulation. Indeed, the concentration of $\mathrm{GnRH}$ receptor in pituitary tissue of ovariectomized sheep is decreased by hypothalamo-pituitary disconnection (Hamernik and Nett, 1988). Surprisingly, the concentration of mRNA encoding $\mathrm{GnRH}$ receptor in pituitary tissue of ovariectomized sheep is not significantly affected by hypothalamo-pituitary disconnec-

* Correspondence.

Received 20 January 1997. tion (Turzillo et al, 1995a). Conversely, pulsatile GnRH stimulation induces a marked increase in the concentrations of mRNA encoding GnRH receptor in pituitary cells of rats (Kaiser et al., 1993). Similarly, the concentration of mRNA encoding GnRH receptor is reduced in the pituitary tissue of rats in which GnRH secretion is blocked by administration of pentobarbital (Bauer-Dantoin et al., 1995). Concentrations of $\mathrm{GnRH}$ receptor and mRNA encoding $\mathrm{GnRH}$ receptor are also reduced in sheep made insensitive to GnRH by administration of a $\mathrm{GnRH}$ antagonist or prolonged treatment with a potent GnRH agonist (Brooks and McNeilly, 1994).

Bauer-Dantoin et al. (1995) suggested that oestrogenic induction of tissue concentrations of mRNA encoding GnRH receptor reflects oestrogenic actions primarily at hypothalamic loci. However, oestrogen-induced increases in the tissue concentrations of $\mathrm{GnRH}$ receptor and mRNA encoding $\mathrm{GnRH}$ receptor are evident in ovariectomized sheep with hypothalamo-pituitary disconnection (Turzillo et al., 1995a). The oestrogenic response is also evident in sheep made resistant to $\mathrm{GnRH}$ by prolonged administration of a potent GnRH agonist (Brooks and McNeilly, 1994). In the studies reported here, orchidectomized sheep (wethers) were used to assess the interaction between physiological concentrations of oestradiol and $\mathrm{GnRH}$ on expression of $\mathrm{GnRH}$ receptor and mRNA encoding GnRH receptor. We hypothesized that oestrogenic stimulation would increase 
tissue concentrations of GnRH receptor and mRNA encoding $\mathrm{GnRH}$ receptor even in wethers made deficient in $\mathrm{GnRH}$ by passive immunization.

\section{Materials and Methods}

Animals

Crossbred whiteface sheep were castrated within 2 weeks of birth. The orchidectomized lambs (wethers) were housed in an open-sided barn under natural lighting and were afforded free access to water and alfalfa pellets supplemented with cereal grains and a vitamin and mineral premix. The studies described here were conducted during the early summer, a period of seasonal anoestrus in female sheep at this latitude $\left(38^{\circ} \mathrm{N}\right)$. The wethers were $6-8$ months of age (bodyweight $=45-50 \mathrm{~kg}$ ) at the time of experimentation. All experimental procedures involving the use of animals were conducted in accordance with National Institutes of Health (NIH) Guidelines and were reviewed and approved by the Animal Use and Care Committee of the University of California.

\section{Cannulation}

Before experimentation, two polyethylene cannulae (Intramedic PE 190, Clay Adams, Parsippany, NJ) were inserted into the left jugular vein. These cannulae were used for intravenous delivery of antisera and continuous infusion of oestradiol or vehicle. A third cannula, inserted into the contralateral vein, was used for blood collection. All cannulae were passed through a protective Tygon tubing sheath to the exterior of the animal holding area. Animals were freely mobile at the end of a $1 \mathrm{~m}$ lead.

\section{Hormone delivery}

The oestradiol delivery cannulae were connected to syringes placed in Harvard infusion pumps (Model 2265, Harvard Bioscience, South Natick, MA). Oestradiol $\left(2 \mu \mathrm{g} \mathrm{ml}^{-1}\right.$; Sigma Chemical Co., St Louis, MO) in 10\% ethanol-saline (vehicle), or vehicle alone, was continuously infused $\left(1 \mathrm{ml} \mathrm{h}^{-1}\right)$.

\section{Active immunization of donor sheep}

Antibodies directed against GnRH were generated in wethers by active immunization with a GnRH-keyhole limpet haemocyanin (GnRH-KLH) conjugate using procedures described by Adams and Adams (1986). A 1:40 000 dilution of the pool of anti-GnRH sera used in this study bound $41.7 \%$ of ${ }^{125}$ I-labelled GnRH added. Anti-KLH sera was obtained from wethers actively immunized against KLH alone.

\section{Immunoneutralization of $\mathrm{GnRH}$ and concurrent oestradiol infusion}

Twenty-four wethers were assigned at random to one of four groups ( $n=6$ animals per group) in a $2 \times 2$ factorial experiment designed to assess the effect of oestradiol and immunoneutralization of endogenous $\mathrm{GnRH}$ on steady-state concentrations of $\mathrm{GnRH}$ receptor and mRNA encoding $\mathrm{GnRH}$ receptor. At passive immunization, $200 \mathrm{ml}$ of ovine anti-KLH (groups 1 and 3) or anti-GnRH (groups 2 and 4) sera was infused (i.v.) over $30 \mathrm{~min}$. Oestradiol was delivered as a continuous infusion $\left(2 \mu \mathrm{g} \mathrm{h}^{-1}\right.$ ) to wethers in groups $\mathrm{I}$ (KLH/ oestradiol) and 2 (GnRH/oestradiol). Animals in groups 3 $(\mathrm{KLH} / \mathrm{V})$ and $4(\mathrm{GnRH} / \mathrm{V})$ were infused with vehicle alone. Infusion of oestradiol or vehicle was initiated at passive immunization and continued for $48 \mathrm{~h}$. Blood samples were collected at passive immunization and at 3,6 or $12 \mathrm{~h}$ intervals thereafter. Serum was harvested and stored frozen at $-20^{\circ} \mathrm{C}$ for later analysis of anti-GnRH titre and concentrations of $\mathrm{LH}$, FSH and oestradiol. At the end of the $48 \mathrm{~h}$ infusion, animals were stunned by means of a captive bolt pistol and killed by exsanguination at the UC Davis Slaughter Facility. Anterior pituitary tissue was quickly excised, halved by a midsagittal cut and each half was immediately frozen in liquid nitrogen and stored at $-80^{\circ} \mathrm{C}$ for later analysis.

\section{Endocrine analysis}

Serum concentrations of $\mathrm{LH}, \mathrm{FSH}$ and oestradiol were determined using previously validated procedures (Adams et al, 1975, 1988; Sakurai et al., 1992). The LH and FSH reference standards (NIAMDD-oLH-25 and NIAMDD RP-1, respectively) were gifts of the National Hormone and Pituitary Program of the National Institute of Arthritis, Metabolism, and Digestive Diseases (NIAMDD; Baltimore, MD). In all cases, intra- and interassay coefficients of variation were $<10 \%$. Anti-GnRH titre was determined as described by Sakurai $e$ t al. (1992). Briefly, 8 fmol ${ }^{125}$ I-labelled GnRH (20 000 c.p.m.) in $0.1 \mathrm{ml}$ of $0.1 \mathrm{~mol} \mathrm{PBS} \mathrm{I}^{-1}$ containing $0.1 \%(\mathrm{w} / \mathrm{v})$ gelatin (Gel-PBS) was combined with $0.1 \mathrm{ml}$ of a $1: 100$ or $1: 1000$ serum:Gel-PBS dilution. After incubation for $24 \mathrm{~h}$ at $4^{\circ} \mathrm{C}$, the radiolabelled GnRH not bound to antibody was separated by precipitation with $95 \%$ ethanol. Anti-GnRH titre in sheep passively immunized with anti-GnRH sera is expressed as percentage of total ${ }^{125}$ I-labelled GnRH bound by $0.1 \mathrm{ml}$ of a 1:1000 dilution of serum.

The affinity and tissue concentration of $\mathrm{GnRH}$ receptor were quantified by means of the procedure described by Sakurai and Adams (1991). Tissue concentrations of mRNA encoding $\mathrm{GnRH}$ receptor were determined using the solution hybridization-RNase protection assay described by Adams et al. (1996). A plasmid containing the cDNA insert for the ovine GnRH receptor (Brooks et al., 1993) was kindly provided by J. Brooks (MRC Reproductive Biology Unit, Edinburgh). The sense and anti-sense cRNAs were generated from linearized cDNA by in vitro transcription using either T7 or SP6 RNA polymerase and the Riboprobe Gemini System II reagent system (Promega Corp., Madison, WI).

\section{Statistical analysis}

Wethers were assigned to one of four treatment groups in a $2 \times 2$ factorial experiment, with the factors of interest being oestradiol infusion and administration of anti-GnRH sera. The significance of treatments was assessed by two-way ANOVA (Gill, 1978). Where significant treatment effects were noted, 
comparison between means was made using Duncan's multiple range test. Data are presented in the text and figures as means \pm SEM.

\section{Results}

\section{Anti-GnRH titre and serum concentrations of oestradiol}

Administration of $200 \mathrm{ml}$ of ovine anti-GnRH sera increased anti-GnRH titre in recipient wethers to $76.7 \pm 0.5 \%$ (percentage ${ }^{125}$ H-labelled GnRH bound by a 1:1000 dilution of serum; $n=12$ ) within $3 \mathrm{~h}$ of passive immunization. Anti-GnRH titre at tissue collection, $48 \mathrm{~h}$ after passive immunization, was $73.5 \pm 0.7 \%(n=12)$. Anti-GnRH titre was not evident $(<1 \%$ ${ }^{125}$ I-labelled GnRH bound by a 1:100 dilution of serum; $n=12$ ) in wethers passively immunized against KLH.

Delivery of oestradiol at a rate of $2 \mu \mathrm{g} \mathrm{h}^{-1}$ established a serum concentration of oestradiol of $11.8 \pm 0.6 \mathrm{pg} \mathrm{ml}-1$ $(n=12)$ within $3 \mathrm{~h}$ of the start of infusion. Serum oestradiol was maintained at this concentration throughout the remainder of the infusion period. At tissue collection, the mean serum concentration of oestradiol in wethers receiving exogenous oestradiol was $12.1 \pm 0.5 \mathrm{pg} \mathrm{ml}^{-1}(n=12)$. The concentration of oestradiol in serum of wethers receiving vehicle was below the sensitivity of the assay $\left(<0.6 \mathrm{pg} \mathrm{ml}^{-1}\right)$.

\section{Serum concentrations of $\mathrm{LH}$ and FSH}

Passive immunization with anti-KLH sera led to a modest and short-lived decrease in serum concentrations of $\mathrm{LH}$ in control wethers receiving vehicle alone (Fig. 1). Serum concentrations of $\mathrm{LH}$ in control animals returned to pretreatment concentrations (15.4 $\pm 1.9 \mathrm{ng} \mathrm{ml}^{-1}$ ) within $12 \mathrm{~h}$ of passive immunization and continued at this concentration for the remainder of the experiment. Conversely, passive immunization with anti-GnRH sera induced a rapid and persistent reduction in the serum concentration of $\mathrm{LH}$. Continuous infusion of oestradiol alone, or in combination with administration of anti-GnRH sera, had a similar effect. At the end of the $48 \mathrm{~h}$ infusion, serum concentrations of $\mathrm{LH}(6.0 \pm 1.4$ and $5.3 \pm 1.2 \mathrm{ng} \mathrm{ml}^{-1}$ ) in wethers receiving oestradiol (KLH/ oestradiol and GnRH/oestradiol, respectively) were significantly lower than $\mathrm{LH}$ concentrations $\left(16.2 \pm 0.8 \mathrm{ng} \mathrm{ml}^{-1}\right)$ in wethers receiving anti-KLH and vehicle (KLH/vehicle). The final serum concentration of $\mathrm{LH}\left(2.6 \pm 0.4 \mathrm{ng} \mathrm{ml}^{-1}\right)$ in wethers passively immunized against $\mathrm{GnRH}$ and receiving vehicle alone (GnRH/vehicle) was significantly lower than the final concentration of $\mathrm{LH}$ in all other treatment groups.

Similarly, when expressed relative to pretreatment concentrations of FSH $\left(18.5 \pm 2.5 \mathrm{ng} \mathrm{ml}^{-1}\right)$, infusion of oestradiol (KLH/oestradiol; $11.3 \pm 1.4 \mathrm{ng} \mathrm{ml}^{-1}$ ) or passive immunization against $\mathrm{GnRH}\left(\mathrm{GnRH} /\right.$ vehicle; $12.9 \pm 1.3 \mathrm{ng} \mathrm{ml}^{-1}$ ) alone, or in combination (GnRH/oestradiol; $11.8 \pm 1.5 \mathrm{ng} \mathrm{ml}^{-1}$ ), significantly reduced serum concentrations of FSH by the end of the $48 \mathrm{~h}$ infusion (Fig. 1). Conversely, passive immunization with anti-KLH sera did not significantly affect serum concentrations of FSH (KLH/vehicle; $19.9 \pm 2.4 \mathrm{ng} \mathrm{ml}^{-1}$ ) $48 \mathrm{~h}$ after passive immunization.
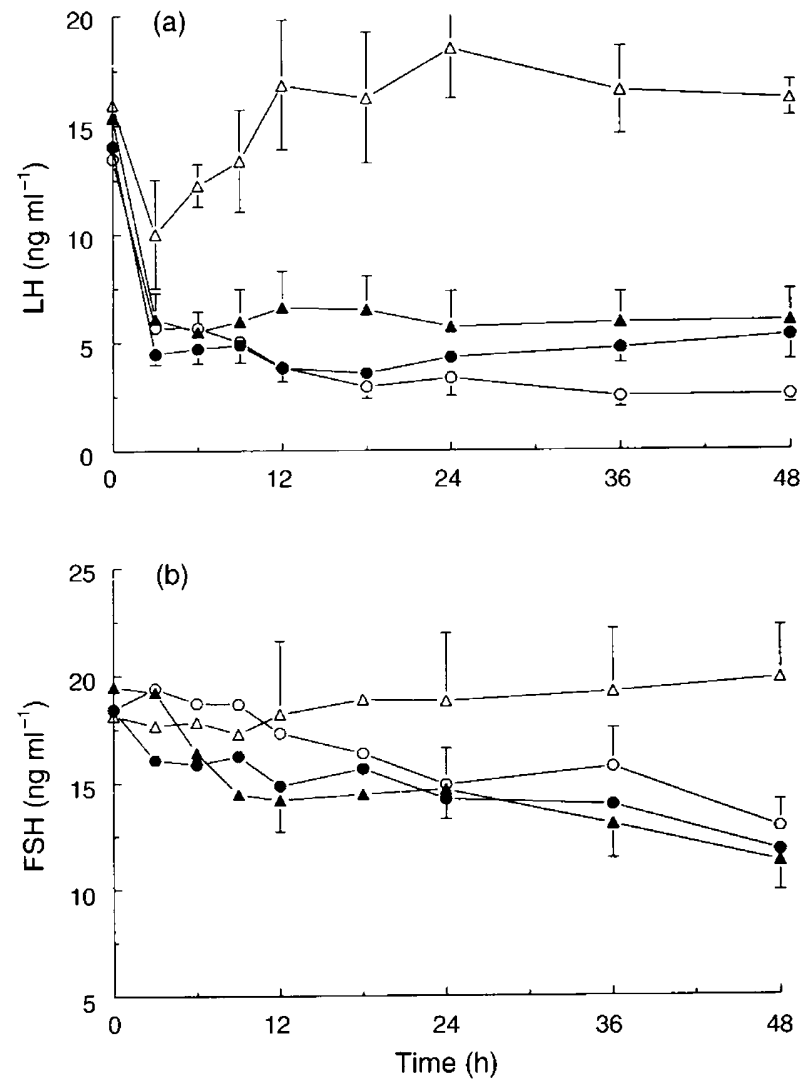

Fig. 1. Serum concentrations of (a) LH and (b) FSH in orchidectomized sheep (wethers; $n=6$ wethers per group) receiving $200 \mathrm{ml}$ ovine anti-GnRH $(O, 0)$ or ovine anti-KLH $(\Delta, \boldsymbol{\Delta})$ sera i.v. at time 0 (passive immunization). Oestradiol (O, $\mathbf{\Delta} ; 2 \mu \mathrm{g} \mathrm{h}^{-1}$ in $10 \%$ ethanolsaline vehicle) or vehicle alone $(O, \Delta)$ was delivered by continuous infusion during the $48 \mathrm{~h}$ period after passive immunization. At certain time points, mean FSH concentrations are depicted without error bars to improve the clarity of graphical presentation.

\section{Steady-state concentrations of $G n R H$ receptor and $m R N A$ encoding $\mathrm{GnRH}$ receptor}

In comparison with control animals (KLH) vehicle $=5.8 \pm 0.8 \mathrm{fmol} \mathrm{mg}^{-1}$ fresh tissue equivalent (FTE)), the concentration of GnRH receptors in pituitary tissue was significantly increased by infusion of oestradiol (KLH/ oestradiol $=11.4 \pm 1.2 \mathrm{fmol} \mathrm{mg}^{-1}$ FTE) for $48 \mathrm{~h}$ (Fig. 2). Concurrent administration of anti-GnRH did not significantly affect the concentration of $\mathrm{GnRH}$ receptor in wethers receiving vehicle $\left(\mathrm{GnRH} /\right.$ vehicle $\left.=5.0 \pm 1.2 \mathrm{fmol} \mathrm{mg}^{-1} \mathrm{FTE}\right)$ or oestradiol (GnRH/oestradiol $=10.4 \pm 0.7 \mathrm{fmol} \mathrm{mg}^{-1} \mathrm{FTE}$ ). Conversely, infusion of oestradiol and administration of anti-GnRH sera had divergent effects on steady-state concentrations of mRNA encoding $\mathrm{GnRH}$ receptor (Fig. 2). Although no significant interaction $(P>0.05)$ among treatments was noted, infusion of oestradiol increased $(P<0.001)$, and administration of anti-GnRH decreased $(P<0.005)$, tissue concentrations of mRNA encoding GnRH receptor. Administration of antiGnRH sera decreased $(P<0.05)$ the concentration of mRNA encoding GnRH receptor (GnRH/vehicle $=0.27 \pm 0.03 \mathrm{pg}$ $\mu \mathrm{g}^{-1}$ total RNA), relative to the concentration noted in control wethers $\left(\mathrm{KLH} /\right.$ vehicle $=0.50 \pm 0.05 \mathrm{pg} \mathrm{\mu g}^{-1}$ total 

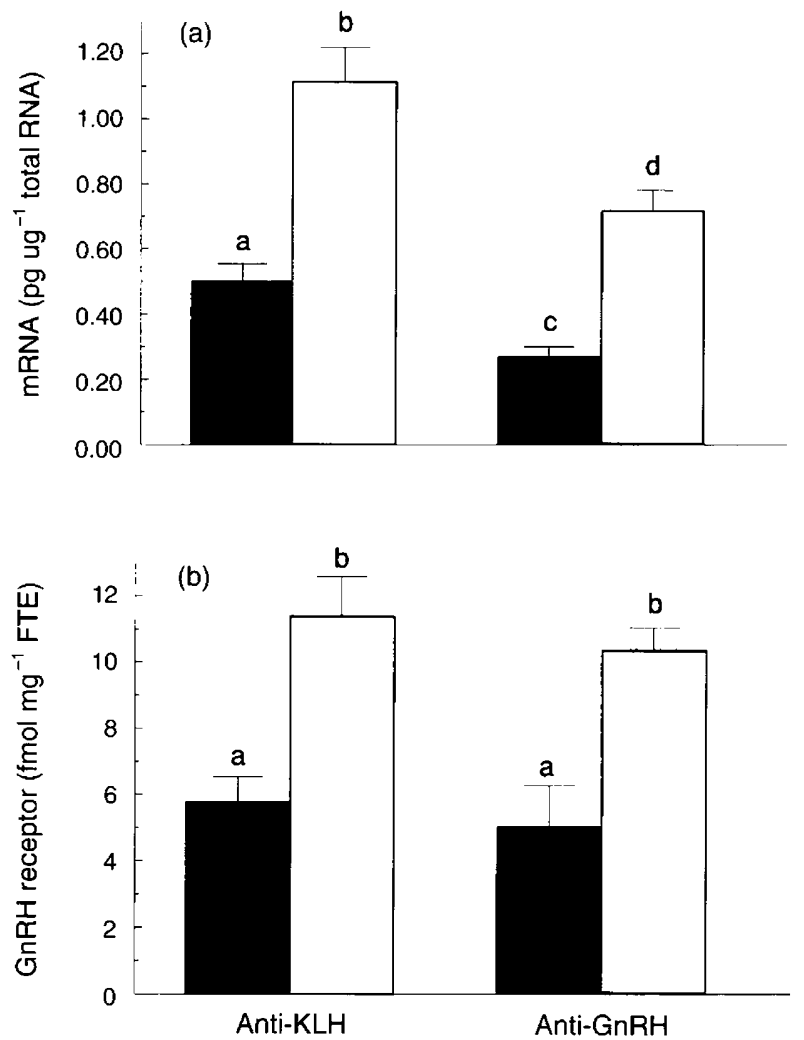

Fig. 2. Steady-state concentrations of (a) mRNA encoding GnRH receptor and (b) GnRH receptor in pituitary tissue of orchidectomized sheep (wethers; $n=6$ wethers per group). Pituitary tissue was collected $48 \mathrm{~h}$ after passive immunization with ovine anti.GnRH or ovine anti-keyhole limpet haemocyanin (anti-KLH) sera $(200 \mathrm{ml}$, i.v.). Wethers received oestradiol ( $\square ; 2 \mu \mathrm{g} \mathrm{h}^{-1}$ in $10 \%$ ethanol-saline vehicle) or vehicle alone ( $\boldsymbol{a}$ ) by continuous infusion during the $48 \mathrm{~h}$ after passive immunization. FTE, fresh tissue equivalent.

RNA). Conversely, infusion of oestradiol increased $(P<0.05)$ the tissue concentration of mRNA encoding $\mathrm{GnRH}$ receptor

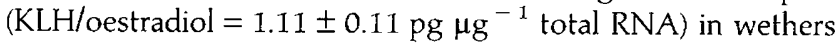
receiving anti-KLH sera. When delivered in combination, anti-GnRH sera reduced $(P<0.05)$, but did not eliminate, the oestradiol-induced augmentation of steady-state concentrations of mRNA encoding GnRH receptor (GnRH/ oestradiol $=0.71 \pm 0.07 \mathrm{pg}^{-1} \mathrm{~g}^{-1}$ total RNA). Indeed, the magnitude of the oestradiol-induced increase in steady-state concentration of mRNA encoding GnRH receptor above basal concentrations did not differ $(P>0.05)$ in wethers receiving anti-KLH or anti-GnRH sera $(0.61 \pm 0.12$ and $0.44 \pm 0.08 \mathrm{pg}$ $\mu \mathrm{g}^{-1}$ total $\mathrm{RNA}$, respectively).

\section{Discussion}

Tissue concentrations of GnRH receptor and mRNA encoding $\mathrm{GnRH}$ receptor are increased by oestradiol and GnRH itself (Turzillo et al., 1995b; Adams et al., 1996). However, the extent to which change in tissue concentration of $\mathrm{GnRH}$ receptor and mRNA encoding GnRH receptor is dependent on interaction between oestradiol and GnRH has not been precisely defined. In the study presented here, orchidectomized sheep made deficient in GnRH by passive immunization were used to examine the hypothesis that the oestradiol-induced increase in tissue concentration of mRNA encoding GnRH receptor is independent of GnRH. In this animal model, serum concentrations of oestradiol comparable with those noted during the periovulatory period in female sheep (10-12 $\mathrm{pg} \mathrm{ml}^{-1}$ ) are established by continuous infusion of exogenous oestradiol.

As demonstrated here and in previous studies (Sakurai and Adams, 1991; Sakurai et al., 1997), intravenous administration of ovine anti-GnRH sera leads to a rapid and persistent reduction in the serum concentration of LH. Passive immunization against $\mathrm{GnRH}$ also dampens the episodic pattern of $\mathrm{LH}$ secretion (Herman and Adams, 1990). These observations indicate that passive immunization establishes an immunological barrier between the hypothalamus and anterior pituitary that markedly reduces the passage of endogenous GnRH. Similar patterns of change in the serum concentration of $\mathrm{LH}$ are noted in ovariectomized sheep after withdrawal of GnRH stimulation effected by hypothalamo-pituitary disconnection (Hamernik et al., 1986; Hamernik and Nett, 1988), pentobarbital-induced anaesthesia (Wright and Clarke, 1988), or administration of a GnRH antagonist (Sanchez ef al., 1994).

Continuous infusion of oestradiol also decreases the serum concentration of LH. This effect of oestradiol is likely to reflect oestrogenic action at both hypothalamic and pituitary loci (Lubbers et al., 1996). Our recent observation (Sakurai and Adams, 1991; Sakurai et al., 1996) that the acute oestradioldependent decrease in serum $\mathrm{LH}$ is not affected by concurrent pulsatile delivery of exogenous GnRH suggests that oestradiol acts directly at the pituitary to reduce gonadotrope responsiveness. Conversely, the decrease in serum LH noted during chronic oestrogen stimulation is reversed by episodic administration of GnRH (Sakurai and Adams, 1991; Sakurai et al., 1996), indicating that the effect of more extended oestrogenic stimulation is manifest primarily at hypothalamic sites.

Although the serum concentration of LH was significantly depressed by either infusion of oestradiol or immunoneutralization of $\mathrm{GnRH}$, the extent of reduction in serum $\mathrm{LH}$ was greater in animals deprived of endogenous GnRH. The final serum concentration of $\mathrm{LH}$ in wethers receiving both antiGnRH sera and oestradiol was significantly greater than the serum concentration of $\mathrm{LH}$ in animals receiving anti-GnRH sera alone. This apparent potentiation of basal LH secretion by oestradiol is consistent with previous observations (Sakurai and Adams, 1991). Similar oestradiol-induced augmentation of basal $\mathrm{LH}$ secretion has been noted in vitro using ovine or rat pituitary cells (Huang and Miller, 1980; Liu and Jackson, 1988; Liu et al., 1993). Although the mechanism of this oestrogenic response has not been fully resolved, several reports indicate that oestradiol enhances the activity of second messenger systems involved in LH secretion (Liu and Jackson, 1988; Fahmy et al., 1989; Ortmann et al., 1995).

Withdrawal of endogenous GnRH by passive immunization also reduced tissue concentrations of mRNA encoding GnRH receptor. This is consistent with previous observations (Sakurai et al., 1997) and indicates that GnRH stimulation plays an essential role in maintenance of tissue concentrations of mRNA encoding GnRH receptor. Although Turzillo et al. (1995a) have reported that tissue concentrations of mRNA encoding GnRH 
receptor were not acutely affected by withdrawal of hypothalamic support, most other work suggests that maintenance of tissue concentrations of mRNA encoding GnRH receptor is critically dependent on continued GnRH stimulation. Indeed, tissue concentrations of $\mathrm{GnRH}$ receptor and mRNA encoding GnRH receptor are markedly reduced in sheep treated with a GnRH antagonist (Brooks and McNeilly, 1994). Similarly, episodic GnRH stimulation increased the concentration of GnRH receptor and mRNA encoding GnRH receptor in pituitary tissue of sheep (Hamernik and Nett, 1988; Turzillo et al., 1995b). Pulsatile delivery of $\mathrm{GnRH}$ also increased the concentration of mRNA encoding $\mathrm{GnRH}$ receptor in perifused rat pituitary cells (Kaiser et al., 1993; Bauer-Dantoin et al., 1995). Moreover, suppression of GnRH secretion by pentobarbital administration leads to rapid reduction in the concentration of mRNA encoding GnRH receptor in the pituitary tissue of ovariectomized rats (Bauer-Dantoin et al., 1995). Collectively, these data support the postulate that maintenance of the steady-state concentration of mRNA encoding $\mathrm{GnRH}$ receptor requires continued GnRH stimulation. This dependence probably reflects, at least in part, a GnRH-induced increase in GnRH receptor gene transcription. Indeed, transcription of a reporter gene linked to the $5^{\prime}$-flanking region of the mouse GnRH receptor gene is increased markedly during stimulation by a GnRH agonist (Albarracin et al., 1994).

Withdrawal of endogenous GnRH support by passive immunization significantly decreased tissue concentrations of mRNA encoding GnRH receptor, without effecting comparable change in tissue concentration of the receptor itself. Similar divergence between tissue concentrations of the receptor and receptor mRNA has been noted by Turzillo et al. (1995a) and Adams et al. (1996) and is likely to reflect differences in the relative stability of mRNA and protein rather than variation in $\mathrm{GnRH}$ dependence. Indeed, we have shown that more extended exposure to anti-GnRH-containing sera significantly reduces tissue concentrations of both GnRH receptor and receptor mRNA in wethers (Sakurai et al., 1997).

The results presented here demonstrate that physiological concentrations of oestradiol increase tissue concentrations of $\mathrm{GnRH}$ receptor and mRNA encoding GnRH receptor in orchidectomized sheep. Oestradiol also increases concentrations of GnRH receptor and mRNA encoding $\mathrm{GnRH}$ receptor in ovariectomized sheep (Turzillo et al., 1994). This oestrogenic effect is likely to reflect a direct action of oestradiol at adenohypophyseal loci. Indeed, an oestradiol-induced increase in the tissue concentration of $\mathrm{GnRH}$ receptor and mRNA encoding $\mathrm{GnRH}$ receptor is evident in ovariectomized sheep made deficient in GnRH by hypothalamo-pituitary disconnection (Gregg and Nett, 1989; Turzillo et al., 1995a). Similarly, oestradiol-induced augmentation of tissue concentrations of mRNA encoding $\mathrm{GnRH}$ receptor has been reported in sheep, even after prolonged administration of a $\mathrm{GnRH}$ agonist (Brooks and McNeilly, 1994). This oestrogenic response is also evident in vitro (Wu et al., 1994). Collectively, these data indicate that oestradiol increases tissue concentrations of GnRH receptor and mRNA encoding GnRH receptor via a $\mathrm{GnRH}$-independent mechanism.

Oestradiol-induced change in the steady-state concentration of mRNA encoding GnRH receptor may reflect a change in rate of gene transcription or a change in mRNA stability, or both. The relative significance of these potential oestrogensensitive processes is not known. However, increased gene transcription is likely to account, at least in part, for the oestradiol-induced increase in steady-state concentrations of mRNA encoding GnRH receptor reported in the present study since the oestradiol-induced increase in GnRH receptor is suppressed by actinomycin D (Gregg et al., 1990). Kimura et al. (1994) have suggested that the oestradiol-induced increase in mRNA encoding thyrotrophin-releasing hormone receptor is due to oestrogen-specific enhancement of both thyrotrophinreleasing hormone receptor gene transcription and mRNA stability.

Taken together, these data demonstrate that maintenance of steady-state concentrations of mRNA encoding GnRH receptor in pituitary tissue requires continued $\mathrm{GnRH}$ stimulation. In contrast, oestradiol-induced increase in tissue concentrations of GnRH receptor and mRNA encoding GnRH receptor is independent of GnRH and is manifest even in sheep made deficient in $\mathrm{GnRH}$ by passive immunization.

Supported by USDA Grant 93-37202-9111 and the California Agricultural Experiment Station.

\section{References}

Adams BM, Sakurai H and Adams TE (1996) Concentrations of gonadotropinreleasing hormone $(\mathrm{GnRH})$ receptor messenger ribonucleic acid in pituitary tissue of orchidectomized sheep: effect of estradiol and GnRH Biology of Reproduction 54 407-412

Adams TE and Adams BM (1986) Gonadotrope function in ovariectomized ewes actively immunized against gonadotropin-releasing hormone ( $\mathrm{GnRH}$ ) Biology of Reproduction 35 360-367

Adams TE, Kinder JE, Chakraborty PK, Estergreen VL and Reeves JJ (1975) Ewe luteal function influenced by pulsatile administration of synthetic LHRH/ FSHRH Endocrinology 97 1460-1467

Adams TE, Quirke JF, Hanrahan JP, Adams BM and Watson JG (1988) Gonadotrophin secretion during the periovulatory period in Galway and Finnish Landrace ewes and Finnish Landrace ewes selected for high ovulation rate journal of Reproduction and Fertility 83 575-584

Albarracin CT, Kaiser UB and Chin WW (1994) Isolation and characterization of the 5'-flanking region of the mouse gonadotropin-releasing hormone receptor gene Endocrinology 135 2300-2306

Bauer-Dantoin AC, Hollenberg AN and Jameson JL (1993) Dynamic regulation of gonadotropin-releasing hormone receptor mRNA levels in the anterior pituitary gland during the rat estrous cycle Endocrinology 133 1911-1914

Bauer-Dantoin AC, Weiss J and Jameson JL (1995) Roles of estrogen, progesterone, and gonadotropin-releasing hormone (GnRH) in the control of pituitary GnRH receptor gene expression at the time of the preovulatory gonadotropin surges Endocrinology $1361014-1019$

Brooks J and McNeilly AS (1994) Regulation of gonadotrophin-releasing hormone receptor mRNA expression in the sheep Journal of Endocrinology 143 175-182

Brooks J, Taylor PL, Saunders PT, Eidne KA, Struthers WJ and McNeilly AS (1993) Cloning and sequencing of the sheep pituitary gonadotropin-releasing homone receptor and changes in expression of its mRNA during the estrous cycle Molecular and Cellular Endocrinology 94 R23-R27

Fahmy NW, Das S and Bourne GA (1989) Dependency of phorbol ester-induced gonadotropin secretion on estradiol Molecular and Cellular Endocrinology 66 9-15

Gill JL (1978) Design and Analysis of Experiments in the Animal and Medical Sciences lowa State University Press, Ames, IA.

Gregg DW and Nett TM (1989) Direct effects of estradiol-17 $\beta$ on the number of gonadotropin-releasing hormone receptors in the ovine pituitary Biology of Reproduction 40 288-293

Gregg DW, Allen MC and Nett TM (1990) Estradiol-induced increase in number of gonadotropin-releasing hormone receptors in cultured ovine pituitary cells Biology of Reproduction 43 1032-1036 
Hamernik DL and Nett TM (1988) Gonadotropin-releasing hormone increases the amount of messenger ribonucleic acid for gonadotropins in ovariectomized ewes after hypothalamic-pituitary disconnection Endocrinology 122 959-966

Hamernik DL, Crowder ME, Nilson JH and Nett TM (1986) Measurement of messenger ribonucleic acid for luteinizing hormone $\beta$-subunit, $\alpha$-subunit, growth hormone, and prolactin after hypothalamic pituitary disconnection in ovariectomized ewes Endocrinology 119 2704-2710

Hamernik DL, Clay CM, Turzillo A, Van Kirk EA and Moss GE (1995) Estradiol increases amounts of messenger ribonucleic acid for gonadotropin-releasing hormone receptors in sheep Biology of Reproduction 53 179-185

Herman ME and Adams TE (1990) Gonadotropin secretion in ovariectomized ewes: effect of passive immunization against gonadotropin-releasing hormone (GnRH) and infusion of a GnRH agonist and estradiol Biology of Reproduction 42 272-280

Huang ES and Miller WL (1980) Effects of estradiol-17 $\beta$ on basal and luteinizing hormone releasing hormone-induced secretion of luteinizing hormone and follicle stimulating hormone by ovine pituitary cell culture Biology of Reproduction 23 124-134

Kaiser UB, Jabubowiak A, Sternberger A and Chin WW (1993) Regulation of rat pituitary gonadotropin-releasing hormone receptor mRNA levels in vivo and in vitro. Endocrinology $133931-934$

Kimura N, Arai K, Sahara Y, Suzuki H and Kimura N (1994) Estradiol transcriptionally and post-transcriptionally up-regulates thyrotropin-releasing hormone receptor messenger ribonucleic acid in rat pituitary cells Endocrinology $134432-440$

Liu TC and Jackson GL (1988) Actions of $17 \beta$-estradiol on gonadotropin release induced by drugs that activate intracellular signal transduction mechanisms in rat anterior pituitary cells Biology of Reproduction $39787-796$

Liu TC, Pu HF and Wang PS (1993) Unimpaired postreceptor regulation of luteinizing hormone secretion by gonadotropin-releasing hormone and estrogen in aged rat anterior pituitary cells Endocrinology 132 1189-1194

Lubbers LS, Hileman SM, Kuehl DE, Ferreira SA and Jackson GL (1996) Effect of estradiol $(E)$ in luteinizing hormone-releasing hormone (LHRH) and LH release in male sheep Society for Neuroscience Abstracts 22 (Abstract 533.3)

Ortmann O, Bakhit M, Bloh P, Schulz KD and Emons G (1995) Ovarian steroids modulate gonadotropin-releasing hormone-induced biphasic luteinizing hormone secretory responses and inositol phosphate accumulation in rat anterior pituitary cells and alpha T3-1 gonadotrophs Journal of Steroid Biochemistry and Molecular Biology 54 101-109

Padmanabhan V, Dalkin A, Yasin M, Haisenleder DJ, Marshall JC and Landefeld TD (1995) Are immediate early genes involved in gonadotropin-releasing hormone receptor gene regulation? Characterization of changes in GnRH receptor (GnRH-R), c-fos, and c-jun messenger ribonucleic acids during the ovine estrous cycle Biology of Reproduction 53 263-269

Sakurai $\mathrm{H}$ and Adams TE (1991) Gonadotrope responsiveness in orchidectomized sheep: 1. effect of continuous infusion of estradiol Biology of Reproduction 45 804-810

Sakurai H, Adams BM and Adams TE (1992) Pattern of gonadotropin-releasing hormone (GnRH)-like stimuli sufficient to induce follicular growth and ovulation in ewes passively immunized against GnRH Biology of Reproduction 47 177-184

Sakurai H, Adams BM and Adams TE (1996) Gonadotrope responsiveness in orchidectomized sheep: effect of duration of a simulated follicular phase Journal of Reproduction and Fertility 108 211-217

Sakurai H, Adams BM and Adams TE (1997) Concentrations of gonadotropinreleasing hormone messenger ribonucleic acid in pituitary tissue of orchidectomized sheep: effect of passive immunization against gonadotropinreleasing hormone Journal of Animal Science 75 189-194

Sanchez T, Wehrman ME, Moss GE, Kojima FN, Cupp AS, Bergfeld EG, Peters KE, Mariscal V, Grotjan HE, Kinder JE and Hamernik DL (1994) Differential regulation of gonadotropin synthesis and release in ovariectomized ewes after treatment with a luteinizing hormone-releasing hormone antagonist Biology of Reproduction 51 755-759

Turzillo AM, Campion CE, Clay CM and Nett TM (1994) Regulation of gonadotropin-releasing hormone $(\mathrm{GnRH})$ receptor messenger ribonucleic acid and GnRH receptors during the early preovulatory period in the ewe Endocrinology 135 1353-1358

Turzillo AM, DiGregorio GB and Nett TM (1995a) Messenger ribonucleic acid for gonadotropin-releasing hormone receptor and numbers of gonadotropinreleasing hormone receptors in ovariectomized ewes after hypothalamicpituitary disconnection and treatment with estradiol Journal of Animal Science 73 1784- 1788

Turzillo AM, Juengel JL and Nett TM (1995b) Pulsatile gonadotropin-releasing hormone $(\mathrm{GnRH})$ increases concentrations of $\mathrm{GnRH}$ receptor messenger ribonucleic acid and numbers of $\mathrm{GnRH}$ receptors during luteolysis in the ewe Biology of Reproduction 53 418-423

Wright PJ and Clarke IJ (1988) Pulsatile administration of gonadotrophinreleasing hormone stimulates, in oestrogen-treated anaesthetized ovariectomized ewes, a surge release of LH qualitatively and quantitatively different from that induced by oestradiol in conscious ovariectomized ewes Journal of Endocrinology 116 143-148

Wu JC, Sealfon SC and Miller WL (1994) Gonadal hormones and gonadotropinreleasing hormone ( $\mathrm{GnRH}$ ) alter messenger ribonucleic acid levels for $\mathrm{GnRH}$ receptors in sheep Endocrinology 134 1846-1850 